\title{
Analysis of Game Strategy of Photovoltaic Trade between China and EU
}

\author{
Cheng Li \\ School of Economics and Management \\ Shenyang Aerospace University \\ Shenyang, China \\ sychengli@163.com
}

\begin{abstract}
Under the impact of financial crisis and European sovereign debt crisis, EU's anti-dumping investigation on China's photovoltaic industry as well as chain reactions triggered by the event further deteriorated the development of photovoltaic industry in China. The problems of photovoltaic industry in China lie in not only external factors such as depression in international economies and serious trade protectionism, but also high dependence on foreign countries, backward in core technology, passive responding of enterprises etc.. The essay further introduces the game model and results showed that cooperation is an inevitable choice for China and EU. Finally, the essay puts forward some countermeasures to realize sustainable development of photovoltaic industry in China, including accelerating negotiations on free trade agreements, implementing market diversification, strengthening the core technology innovation, and strengthening the industry warning and responding.
\end{abstract}

Keywords-photovoltaic industry; game strategy; antidumping;anti-subsidy; trade protection

\section{INTRODUCTION}

Because of global financial crisis and European sovereign debt crisis, the demand for photovoltaic (hereinafter PV in short) has a sharp decrease all over the world. At the same time, it also slows down the development of PV industry. On September $6^{\text {th }}, 2012$, European Union officially declared anti-dumping investigation on China's PV modules, key components such as silicon chip. The amount related to this case was over $\$ 20$ billion. This case is also so far the biggest trading lawsuit that the European Union launched to China. On June $4^{\text {th }}$, 2013, the European Union commission announced that they would levy an $11.8 \%$ provisional antidumping tariff on China's PV modules and key components since June $6^{\text {th }}, 2013$. The anti-dumping tariff rate would reach to $47.6 \%$ if China and European Union can't come up with a reasonable solution before August $6^{\text {th }}$, 2013. On July $27^{\text {th }}$, 2013, European Union Commission announced China and European Union had reached "Amity" solution on PV trading dispute. The main contents of the settlement agreement was that about 90 Chinese solar energy companies (accounting for about $60 \%$ of the EU market share) have to make a commitment that the price of export products to the EU would not be less than 56 cents per watt to avoid provisional tariffs from European Union. This agreement was adequate for at most 7,000 megawatts in European Union market share. The
European market total scale will reach to 10,000 to 12,000 megawatts in 2013. This upper limit will be kept to the end of 2015.

In addition to European Union, American PV companies submitted applications of anti-dumping and anti-subsidy investigation on Chinese PV products to the United States Department of Commerce and the United States International Trade Commission on October $19^{\text {th }}$, 2011. Indian solar companies also submitted the application of anti-dumping investigation on solar battery which originated from China to Indian Ministry of Commerce on December 2011. It can be seen that with the increase of foreign trade protection, Chinese PV industry will confront more trade protection barriers in the international market, thereby further affect the development of Chinese solar energy industry as well as the cooperation on new energy field with other countries [1]. Under the impact of external demand market, the domestic PV industry supply and demand appears serious unbalance, resulting in the overcapacity of China's PV industry, serious disruption of exports, the big decrease, loss even closedown of the whole industry. PV industry's development dilemma runs counter to country's macroscopic strategy on cultivation and development of new energy industry, which is worthwhile to call overall attention.

\section{The DeVElopment Status of ChINA's PV INDUSTRY}

China's PV industry entered into steady development stage in the middle of 1990s, and has taken on a rapid development trend in 21 century. China's PV industry has become an important strength of global PV industry.

The global polysilicon production reached 250,000 ton in 2013. Among the world's major polysilicon producers such as the US, South Korea, Germany and Japan, the production of each other was 55,000, 48,000 and 14,000 ton. China's production was about 80,000 ton with an increase of $12.7 \%$ comparing with last year. And china had ranked first in the world for three consecutive years, but it just could meet $50 \%$ market demand of China. China's import of polysilicon would reach 75,000 ton, and Germany, Korea and the US respectively occupied 33\%, $28 \%$ and $26 \%$ in China's total import amounts [2].

The global PV components production reached 40 megawatt in 2013, with an increase of $9 \%$ compared with 2012. Among the main PV components producers such as Europe, Japan and the US, the production of each country 
was 3.5, 2.8 and 1.2 megawatt. China's PV components production was about 26 megawatt, with an increase of $13 \%$ compared with 2012, and it has ranked first in the world for seven consecutive years. In the aspect of export, China exported about 16 megawatt of PV components, and the total amount was about $\$ 10$ billion, with a decrease of $27 \%$ compared with 2012. The quota of PV components exporting to Europe decreased to $30 \%$ in 2013 from $65 \%$ in 2012. However, Japan leaped to the first and became to the biggest export country. The total export amount was about $\$ 2.2$ billion in 2013, accounting for $22 \%$ in the world export amount. The quota of PV components exporting to the US, India and South Africa were 10\%, $5.2 \%$ and $4.5 \%$, appearing pluralism develop trend. In the aspect of import, under the impact of the US's "Double Reverse", mainland companies mainly adopted battery slice from Taiwan to avoid trade barriers. The amount of battery slice importing from Taiwan was over $\$ 1$ billion, accounting for $60 \%$ in China's total import amount of solar battery [3][4].

However, under the effect of the multiple factors such as the slow-down acceleration of global PV market demand, the increasing obstacle of products outlet, the imbalance of PV industry development and etc., as well as there are so many troublesome problems in the China's domestic PV industry such as disorderly market competition, over dependence of products market on overseas demand, poor ability of technological innovation, the slow development of key technological equipment and materials, the weak financial funds support, the imperfection of subsidy mechanism and etc., PV industry has confronted with severe situation since 2011. The global financial crisis began, and sovereign debt crisis started in different countries and regions at first half year of 2011. These have brought severe impacts on PV industry. While as the trade protection coming up, it has also accelerated the depravation of China's PV industry. It could be seen from the bankruptcy of Wuxi Shangde in 2013 and the renege of Chaori enterprise debt in 2014.

III. ANALYSIS OF CAUSES OF ANTI-DUMPING INVESTIGATION ON CHINA'S PV INDUSTRY BY EU

\section{A. Debt Crisis of Europe sovereign and Raise of Trade Protection}

Europe itself has subsidies for new energy PV industry. European Union issued legally binding "20-20-20" strategy in the reproducible energy and efficiency field in the early 2008, and passed through this strategy through the form of "reproducible energy instruction". Germany government published "solar energy roof plan" and PV net electrovalence strategy, making Germany as the world's PV winner of new energy. Followed by Germany, the European Union countries have published for high policyrelated subsidies for renewable energy industry, such as PV products, PV power generation applications [5]. The European debt crisis starting from 2010 brought great resistance to the world's biggest solar market in Europe. Now Germany PV power generation accounts for $20 \%$ of the total installed capacity, and $80 \%$ of them came from the products made in China. Exports of PV products also account for more than $90 \%$ of the total domestic output in China. Under the impact of products in China, many PV companies could not compete, even went bankrupt in Europe and the United States. Governments in Europe and the United States on the one hand are unwilling to adjoining the inoculation of large PV market for many years, on the other hand they can't allow heavily financial subsidies used in photovoltaic industry flow into foreign enterprises. Therefore many countries have tried to take trade protection means such as "double reverse" to contain the development of China's PV industry.

\section{B. Over dependence of China's PV industry on Foreign Market}

In 2012, the export amount of China's PV products to Europe was $\$ 11.19$ billion with a decrease of $45.1 \%$ compared with 2011 and $10.1 \%$ higher than the overall decline of export. Even so, European Union area is also the biggest overseas market for China PV products, accounting for $46.1 \%$ of total exports amounts. In obvious contrast to this is that exports of China PV to Japan, South Korea and ASEAN increased respectively by $63.4 \%$, $26.8 \%$ and $22.1 \%$, and exports to Africa reached to $10.9 \%$. In 2013, once as the biggest overseas market for China PV industry, the proportion of exports to Europe decreased to $30.26 \%$ from the highest point of $70 \%$. Asian market took the first place, with the proportion of $44.7 \%$. From January to February, 2014, Asian market accounted for $52.39 \%$, and European markets accouted for $22.56 \%$. From January to February, 2014, the proportion of exports to Germany slipped out of top 10, however Japan occupied first, and in the year of 2013 and January and February 2014, the proportion of exports to Japan were $24.63 \%$ and $34.23 \%$. A series of numbers reflected that China's PV industry was seriously affected by overseas market friction and trade policy[6].

\section{Unreasonable Industrial Structure and Lack of Core Competition}

China PV industry develops rapidly, but it can't get rid of unhealthy economic cycle mode of dependence of materials on imports, lacks of core technological equipment and mainly export of products, which is still export-oriented develop mode of "three heads outside"[7]. The technological contents and energy converts rate of PV products fall behind developed countries, lack of core competition. Meanwhile, the processing trade plays the leading position in PV trade. The amount of processing trade of solar PV products was $\$ 6.554$ billion, accounting for $53.3 \%$ in exports. The exports amount of general trade was $\$ 5.042$ billion, accounting for $41.0 \%$, with a decrease of $17.1 \%$ compares with 2012. The great profit at the beginning period of PV industry made many inventors greedy to expand the production and too busy to update technology and R\&D. The dependence of most high grade equipments on imports, the PV production criterion made by foreigners and lack of core technology make poor ability of self-update in China's PV industry, leading to productivity with a large quantity of equipments relative surplus and confront elimination.

\section{Poor Defense Capacity and Adverse Response of Chinese enterprises on the Lawsuit}

According to the provision of WTO1994 anti-dumping regulations sixth item tenth clause, if party can't submit necessary materials in the prescribed limits on dumping 
investigation, the investigate party could make adjudication according to existing truths. That's to say, if the accused dumping enterprise can't submit relevant materials to defense in the limit time, the investigate party could make adjudication according to the materials submitted by appealing country. Most Chinese enterprises didn't respond the lawsuit or dare not to respond lawsuit when they were accused. Exactly because of negative attitudes and nonfeasance of enterprises, EU overrated dumping scale at a big degree, when they made adjudications according to existing materials. The punishment means that enterprises would lose competitiveness and its products would also lose market in a long time if they were adjudicated dumping.

\section{The Choice of GAMES Strategy BeTweEN CHINA AND EU}

\section{A. Win-win Critical Point of PV Trade between China and $E U$}

In the new-high technology business, the enterprises market shares are made by their prices. Different PV products have landscape orientation discrepancies, namely different "place value". Suppose place value of PV products between China and EU lies between 0 and 1 . European consumers need to pay $x \times t$ if they choose Chinese PV products, but if they choose European products, they just need to pay $(1-x) \times t, \boldsymbol{t}$ is differential index, $\mathrm{x}$ is consumption, when

$$
p_{1}^{*}+t x=p_{2}^{*}+(1-x) t
$$

It makes no difference to consume products with two different place values, namely

$$
x=\frac{1}{2}+\left(p_{2}^{*}-p_{1}^{*}\right) / 2 t=\frac{1}{2} *\left[1+\left(p_{2}^{*}-p_{1}^{*}\right) / t\right]
$$

$p_{1}^{*}, \quad p_{2}^{*}$ in the formula are market equilibrium prices. The essay regards EU as exclusive consuming market, and makes Chinese products place value as $x=0$, its demand is

$$
D_{1}=1 / 2+\left(p_{2}^{*}-p_{1}^{*}\right) / 2 t=1 / 2 *\left[1+\left(p_{2}^{*}-p_{1}^{*}\right) / t\right]
$$
is

In that way, demand function of European PV products

$$
D_{2}=1-1 / 2 *\left[1+\left(p_{2}^{*}-p_{1}^{*}\right) / t\right]
$$

Profits functions of PV enterprises in China and EU are

$$
\begin{aligned}
& R_{1}=\left(p_{1}^{*}-c_{1}\right)^{*} D_{1}=x\left(p_{1}^{*}-c_{1}\right) \\
& R_{2}=\left(p_{2}^{*}-c_{2}\right) D_{2}=(1-x)\left(p_{2}^{*}-c_{2}\right)
\end{aligned}
$$

$c_{1}, \quad c_{2}$ in above formulas are respectively the products cost of enterprises in China and EU

$$
c_{1}=\beta * k_{1}^{2}+c_{0}, \quad c_{2}=\beta * k_{2}^{2}+c_{0}
$$

$k_{1}, \quad k_{2}$ are the protection degree of intellectual property of enterprises in China and EU. When $0<k<1$, the bigger $k_{1}$ and $k_{2}$, the higher protection degree. $\beta$ is a influence factor of intellectual property on innovation cost, and $c_{0}$ is fixed cost without protection. Optimum price of enterprises in China and EU can be concluded

$$
\begin{aligned}
& p_{1}^{*}=t+c_{0}+\beta / 3\left(2 k_{1}^{2}+k_{2}^{2}\right) \\
& p_{2}^{*}=t+c_{0}+\beta / 3\left(k_{1}^{2}+2 k_{2}^{2}\right)
\end{aligned}
$$

When the results are balanced, the market shares are

$$
\begin{aligned}
& D_{1}=1 / 2+\beta\left(k_{2}^{2}-k_{1}^{2}\right) / 6 t \\
& D_{2}=1 / 2{ }^{-} \beta\left(k_{2}^{2}-k_{1}^{2}\right) / 6 t
\end{aligned}
$$

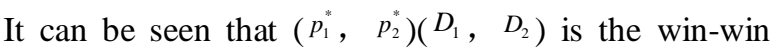
critical point of PV trade between China and EU, at which China and Europe could obtain maximize profit from market share allocations and then realize the win-win result. If EU levies high tariffs on China, the price will be higher than critical point and decrease the market share of China's PV products, so resulting in trade disputes or lossloss and zero-sum game.

\section{B. Cooperation as the Inevitable Choice of Trade Strategy between China and EU}

The win-win critical point of PV industry trade mentioned above is the function of products cost, products differential index and intellectual protection degree. Supposing product technology and resource endowment structure are almost the same in general in China and EU, in that way the products costs are closely interrelated to each country's trade policy.

It can be shown as in Fig. 1, point D represents winwin game point. China's PV products sales are AG, while EU's sales are BG in normal situation. If EU levies high punitive tariffs on China's PV products, the price of China's PV products in EU would increase to from, with the price higher than win-win critical point. Thus the market share of China's PV products in EU will decrease to $\mathrm{AC}$ from $\mathrm{AG}$. If the price of PV products in EU stays the same, market share will increase to BC from BG. If EU levies punitive tariffs on China's PV products as a measure of resistance, it's likely that China will raise the tariff rate from $40 \%$ to $50 \%$ on EU's polysilicon. It would be a big strike for EU's PV industry and make both parties get into a vicious competitive circle of "prisoner dilemma" and zero-sum game. According to the theory of non-zero-sum,

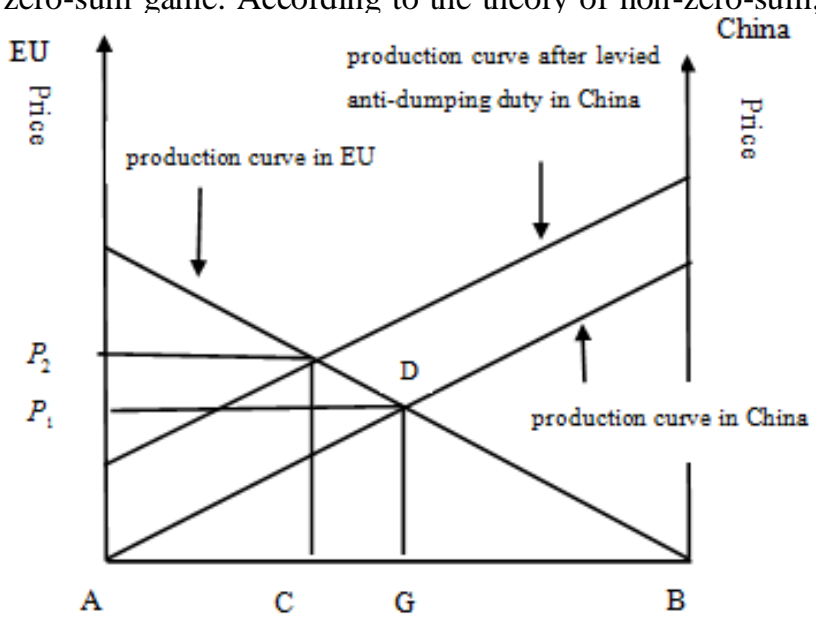

Figure 1. Produce curves of PV industry in China and EU 
it is necessary to build an efficient cooperation mechanism of "encouraging interconsistency" between both game parties. It is an inevitable policy choice for China and EU in PV trade to avoid happening of trade war. In the end, China and EU reach a price promise to adopt the policy of trade cooperation through negotiation, in accordance with the game logic of this essay [8].

\section{COUNTERMEASURE OF RESPONSE ON FOREIGN ANTI-DUMPING FOR CHINA'S PV INDUSTRY}

\section{A. Acceleration of the Negotiation and Signing of Free Trade Agreements}

With the rapid development of international trade, the international format, which is characterized by the "bilateral free trade and transregional free trade", has been gradually emerging. The western developed economic entities and emerging economic entities are appearing a positive acceleration in trade growth. For instance, NAFTA (North America Free Trade Areas) show a steady growth in trade amounts. Internal trade amounts in EU hardly change under the impact of European sovereign debt crisis. Internal trade amounts in ASEAN keep good trend. The bilateral trade achieves sustained growth under the free trade agreements between US and South Korea. Singapore has signed some free trade agreements making trade volume growth accelerate and etc.. All trade data show that who has more free trade agreement countries, who will be the winner in the future world trade. However, in addition to WTO, China only signs 11 free trade agreements at present, and there are also 5 bilateral free trade agreements under negotiation. Therefore, Chinese government is looking for the chance to join into TPP (Trans-Pacific Partnership Agreement). At the same time, we are trying to facilitate the negotiation and the signing of bilateral trade agreements. We try to fulfill free trade negotiation and free trade agreements between China and South Korea, and among China, South Korea and Japan as soon as possible. Meantime, we are changing the diplomatic strategy in the Middle East, and facilitating the free trade agreements with gulf country commissions as soon as possible and guiding the process of RCEP (Regional Comprehensive Economic Partnership) negotiation positively to appreciate the convenience of bilateral and transregional free trade, therefore achieving sustained and rapid growth of international trade[9].

\section{B. Implementation of Diversification of Target Markets}

China's PV market is too intensive and enterprises are over dependent on EU. It will be a fatal effect on China's PV industry if EU attacks China's PV. China should accelerate exploiting other emerging markets, and exploit the fledgling emerging markets such as India, Japan, Southeast Asia and etc. We should facilitate market diversification and reduce dependence on a specific market to reduce the impact of other countries' policy changes on the China's PV industry. On the other hand, domestic market is a big potential market because of large population in China. The state council issued "a number of opinions on healthy development of facilitating PV industry" as well as 9 supportive documents in 2013, including subsidy of generating capacity and management approach of appropriated funds by the Treasury
Department, "The interim management measures of distributed power generation" by National Development and Reform Commission, "standard conditions of PV manufacturing industry" by MIIT and etc. All these try to solve the bottleneck of domestic applying market from multi aspects such as net electric price, subsidy funds, grid-connected management and etc., aiming at accelerating large-scale start of domestic market.

\section{Enhancing Technological Innovation and improving Technical Content of Products}

PV manufacturing industry has gained highly attention as an emerging high-tech industry. EU's PV industry takes up the leading position all the time. It develops rapidly under the guidance of EU's supportive policy, and its development speed has got beyond other countries' expectation. Most Chinese enterprises only pay attention to expanding production, but neglect technical improvement. After European sovereign debt crisis, European PV market contracted, finally resulting bankruptcy because of inventory backlog of Chinese PV. Therefore, Chinese PV industry should strengthen technological innovation. On one hand, we should carry out localization policy on the set of equipments introduced from overseas and pay attention to break up, develop and R\&D of introduced technology and key equipment. On the other hand, we should change the present development mode of introducing a set of equipment gradually and instead introduce technological patents, technical information and basic scientific research achievement, thus achieving proprietary intellectual property rights in the PV industry field. Meantime, we should take advantage of combination of production and research. We should enhance efficient manufacturing technology of PV materials preparation technology, new technology of battery manufacturing including no contact printing, copper electrode, surface perspiration ion injection, etc., technology of the battery materials preparation including silver paste, high transmittance, UV irradiation resistant by PV EVA coating and low-water, gas diffusion back, etc. as well as the R\&D, application and promotion of key equipment including controller, inverter, large hydrogen compressor, etc[10].

\section{Strengthening Industry Warning and Actively Responding}

Relying on the expert working team formed by the government, associating with trade association and enterprises, we should build a risk warning system of covering the whole industry chain, enhance communication and cooperation in international trade risk management field, master the dynamic of industry competition comprehensively and timely, and promote the ability of risk identification and risk treatment. When China's PV export volume is too large and sale price is too low, the system will make early-warning to enterprises to warn enterprises to change its export strategy and coordinate its sale price. At the same time enterprises could have more time to collect information when enterprises suffer from anti-dumping and anti-subsidy investigation. Anti-dumping and anti-subsidy have become common trade measures in international trade field, and they already become common practice of trade protection. However, not all the anti-dumping cases could end with anti-dumping sanction. With successful responding, the 
winner will get out of sanction. The 18th item of EU's anti-dumping laws stipulates handling methods of "noncooperation companies". The anti-dumping competent department could make adjudications according to "available information" if defendants refuse investigation and can't submit necessary materials on time or hinder investigation obviously. If enterprises can't responds actively and submit favorable materials, the anti-dumping competent department will make adjudications according to the information they have mastered or the materials the party submitted, even if these materials are not true. Therefore, every enterprise should build the awareness of rights protection, employ professional lawyer teams to get professional analysis and deraignment, and contend rationally to protect self-interests during the anti-dumping investigation.

\section{CONCLUSIONS}

With worldwide financial crisis and European sovereign debt crisis, EU and some countries implemented anti-dumping and anti-subsidy investigation on China's PV industry, which deteriorated the development of PV industry in China. There are many causes, including debt crisis of European sovereign and raise of trade protection, over dependence of China's PV industry on foreign market, unreasonable industrial structure and lack of core competition, poor defense capacity and adverse response of Chinese enterprises on the lawsuit. The essay further introduces the game model and results showed that cooperation is an inevitable choice for China and EU. Finally, the essay puts forward some countermeasures to realize sustainable development of PV industry in China, including acceleration of the negotiation and signing of free trade agreements, implementation of diversification of target markets, enhancing technological innovation and improving technical content of products, and strengthening industry warning and actively responding.

\section{REFERENCES}

[1] Liao Mei and Zhang Qian, "The Multiple Effects of Penalty Tariff - the Study of Sino-US Trade Friction on China's PV Industry Based on GTAP Model," Jiangsu Commercial Forum, Dec, 2012, pp.63-68

[2] European Photovoltaic Industry Association (EPIA), "Global Market Outlook for Photovoltaics. 2014-2018." http://www.solarpowereurope.org/index.php?id=22

[3] China Chamber of Commerce for Import and Export of Machinery and Electronic Product, Solar Energy Branch. http://www.cccme.org.cn

[4] Outlook for Chinese PV Industry Development in 2014. http://guangfu.bjx.com.cn/news/20131218/480967.shtml

[5] Zhang Tianyu, "The Research on EU for Anti-dumping Issues of Chinese Photovoltaic Products," Master Dissertation from Liaoning University, Jun, 2013

[6] Jiao Long, "The Research on International Competitiveness of Solar Energy Photovoltaic Industry in China," Master Dissertation from Beijing Forestry University, Jun, 2013.

[7] Chen Liyao, "The Research of the Anti-dumping Problem Facing by China's Importing PV Products," Master Dissertation from Ocean University of China, May, 2013.

[8] Hao Zhimin, Youqi, "Analysis of Game Strategy of PV Trade Friction between China and EU," Modern Business,

[9] Yu Nanping, "The Analysis of Dilemma and Prospect of China's Foreign Trade," People's Tribune, Jul, 2013, pp. 32-33

[10] Zhang Yuzhe and Wang Junpei, "The Factors and Strategies of PV Industry Dilemma," Macroeconomic Management, Apr, 2013, pp. $45-47$ 